\title{
Trade Secrets Protection in the Context of Employment in China: the Law and the Business Operations
}

\author{
Chuanhai Chen \\ School of Tourism and Hospitality Management, Southern Cross University, \\ Gold Coast Campus, QLD 4225, Australia \\ E-mail: c.chen.29@scu.edu.au \\ Yahya Al-Ansari \\ Southern Cross Business School, Southern Cross University \\ Gold Coast Campus, QLD 4225, Australia \\ E-mail: y.alansari.10@scu.edu.au
}

\begin{abstract}
This paper presents a study exploring and explaining the risk factors that cause businesses to lose trade secrets. The study examined the role of employees in the process of trade secrets divulgence, employee's confidentiality defined by the law, contractual obligations, inevitable disclosure, civil remedies, agreements and rules, and it also looked at how legal regulations address such risk factors. A range of commonly suggested business procedures in organizations were then examined against the sufficiency of addressing these risk factors. The results of this study have both theoretical and practical contribution towards the understanding of how to do business in china.
\end{abstract}

Keywords: trade secrets; confidentiality; inevitable disclosure; contractual obligations; trade secrets security.

\section{Introduction}

Technology and information are critical for commercial success and economic growth in the knowledge-based economy ${ }^{1}$. There is a range of mechanisms to secure proprietary information and technology from being used by the others, amongst which trade secrets enforcement plays a significant role in protecting competitive advantages $^{2}$. The majority of working technologies worldwide is protected by means of trade secrets rather than patent $^{3}$, particularly when companies have attempted to protect fast-moving new technological developments ${ }^{4}$. Furthermore, some un-registrable information such as customer lists, market data and efficient work procedures can be only protected in the form of trade secrets.

Protecting proprietary technology via secrecy has traditionally prevailed in the Chinese business sector ${ }^{5}$. On the one hand, transferring proprietary technology and know-how down the male lineage of the family has long been a tradition in the family-run businesses in
China $^{6}$, on the other hand, spying on competitor' business secrets or copycatting the other's intellectual property rights has often been considered to be commendable ${ }^{7}$.

The legal protection of trade secrets is relatively new in China as commercial information and technical knowledge have long been treated as state secrets in the planned economy ${ }^{8}$. The Anti-Unfair Competition Law came into force in 1993, marking the inception of legal protection for trade secrets in China ${ }^{9}$. After joining the World Trade Organization (WTO), the legal protection of intellectual property rights has been reinforced through a series of lawmaking and amendments to the exiting legislations and law enforcement ${ }^{10}$. However the legal protection of trade secrets in the employment context remains nebulous; it is often difficult to balance the conflicting interests of employers and employees ${ }^{9}$.

This study aims at investigating how trade secrets are protected in the course of employment in Chinese enterprises. This study drew on the best practices of trade secrets protection worldwide, and then compared 
with the protection provided by the Chinese law and security measures taken by Chinese enterprises so as to better understand how trade secrets are protected in the workplace in China. A case study approach was employed as the principal method of the study. A smallscale case-based investigation was conducted to identify the key risk factors influencing the levels of security of confidential information in Chinese enterprises. The findings of this study will help Chinese business organizations to create new trade secrets protection procedures by optimizing existing measures.

\section{Trade Secrets Protection in the Context of Employment}

There is no universally accepted definition of trade secrets $^{11,3,12}$. According to the WTO Agreement on Trade-Related Aspects of Intellectual Property Rights (TRIPS), to be qualified as legally protected trade secrets, four basic elements need to be addressed.

Firstly, trade secrets must consist of information which commonly falls into two categories: technical information and business information. In contrast with other intellectual property forms, such as copyright and patent, trade secrets cover a broader scope of information ranging from financial status of a business organization, methods of doing business, customer and supplier lists, to the names, even phone numbers of particular employee ${ }^{13}$. Secondly, the information must have independent economic value for its holder ${ }^{14}$, information that confers actual or potential economic value or advantage over competitors can qualify as a trade secret ${ }^{13}$. Thirdly, the information should not be generally known to the public, particularly the competitors. Secrecy has been one of the core concepts of trade secrets law ${ }^{14}$. Lastly, reasonable measures should be taken to maintain that secrecy. Measures taken to secure the information from being disclosed serve as an indicator of confidentiality ${ }^{1}$.

\subsection{Employees as significant risk factor}

Trade secrets owners face various risks of losing trade secrets. In general, the ways through which businesses lose trade secrets can be classified into two categories ${ }^{15}$ : those do not breach the law, such as review of public available records, employment solicitation, joint-venture and acquisitions, conferences and visitors, dumpster diving, and reverse engineering; and those involve illegal activities, such as organized crime, illegal competitive intelligence, elicitation of insiders of business, infiltration into business, recruiting employees through bribery or other illegal means, computer intrusions, burglary and theft, and electronic spy surveillance $^{16,17}$. Many of these risks hinge on the loyalty and integrity of current and former employees ${ }^{18}$,

${ }^{19}$. Research indicates that authorized trade secrets users account for 80 percent of inappropriate disclosure of sensitive information ${ }^{20}$. Put differently, the largest contribution to trade secrets loss, in contrast to other risk factors, comes from within organizations ${ }^{21,22,23}$.

\subsection{Confidential relationships as the legal ground for trade secrets protection}

Many organizations rely on secrecy to protect their valuable information ${ }^{24}$. Trade secrets owners may keep strict secrecy provided that the protective measures taken are sufficient to prevent the information from going public. Unfortunately, it is virtually unavoidable for an organization to share information with its employees on a day-to-day basis.

Trade secrets law has long addressed this dilemma by shedding light on confidential relationship between the discloser of information and the party with whom such information are communicated. The initiation of trade secrets rights can be traced back to early Roman times where Roman law frowned upon enticing a competitor's employees (slaves) to divulge secrets relating to the master's commercial affairs ${ }^{25}$. In modern law, a fundamental principle is that employees owe a duty of care not to disclose the employer's trade secrets $^{26}$.

\subsubsection{Contractual obligations not to disclose or use an employer's trade secrets}

The duty not to disclose or wrongfully use an employer's confidential information is generally based on the contractual relationship ${ }^{27,26}$. In spite of some conceptual overlapping which arises frequently, 'confidentiality agreement', 'non-disclosure agreement', 'non-compete agreement', 'covenant not to compete' are the common expressions used in addressing employees' contractual obligations not to disclose corporate trade secrets ${ }^{28,} 29,26,30$. In this study, "confidentiality agreement" was selected to describe employee's duties not to disclose trade secrets within the terms of employment, while a "covenant not to 
compete" refers to the duties imposed after the termination of employment.

When employment starts, the employer usually asks the employee to sign a non-disclosure agreement (confidentiality agreement), or alternatively inserts similar clauses or provisions as part of, or based on, the employment contract ${ }^{31}$. The employee's duty not to disclose corporate secrets will subsist as long as the employment lasts ${ }^{32}$.

Other than confidentiality agreement which applies during the term of employment, many businesses require employees to sign a covenant not to compete with the employer, or to include a non-competition clause in the employment contract ${ }^{33}$. Although noncompetition agreements are used frequently in business transactions other than employment, such as the sale of a business or dissolution of a partnership ${ }^{11,30,34}$, in this study the consideration was strictly limited to the employment context. Covenants not to compete typically provide that, within a certain period of time after the termination of the employment, or within a certain geographical scope, or both, the departing employee shall not work for a competitor, or start up an own business by virtue of the confidential knowledge or information obtained through the course of former employment $^{35}$. A covenant not to compete can be one of the most powerful tools available to an employer ${ }^{35}$.

Confidentiality agreement typically does not restrain the employee's post-employment rights to use the general skills obtained through former employment and therefore are generally enforceable ${ }^{28}$, while a covenant not to compete appears to restrain competition and impose undue obligation on employees ${ }^{35,11,30}$.

Therefore in many countries covenants restraining employee's rights to further employment are simply forbidden, while in other countries the enforcement of such restraints are restricted by the law ${ }^{30}$.

\subsubsection{The employee's confidentialities based on implied duties}

Governed by the laws of many countries, employees are under an implied duty not to misuse trade secrets acquired during the course of employment when the employee knows or should know, given the circumstances, that the employer intends the information to be kept confidential ${ }^{35,36}$. In general, the confidential information obtained during the course of fiduciary relationships should not be used or disclosed at the detriment to the owner of the information ${ }^{37,26}$.

Not all employment relationships can be qualified as confidential. Confidential relationship can be measured by the nature of the employment, for example, when an employee has intimate knowledge of the employer's business, the relationship between employer and employee may be considered confidential $^{37}$. Implied duty may also be imposed on a person holding a key position in a company. For example, corporate directors owe a fiduciary duty to the corporation ${ }^{38}$, even though there may be no expressed contractual restraints in place, the directors are imposed an obligation by law.

Non-competition covenants were expanded to include the protection of all kinds of business information in some countries, even if the information is not eligible to be classified as a trade secret ${ }^{39}$. Corporations often impose a non-compete duty against employees on the grounds of the inevitable disclosure ${ }^{26}$. The doctrine of inevitable disclosure recognizes that in certain circumstances the employee can by no means compartmentalize the knowledge and experience obtained during the course of former employment, thus the employee will inevitably disclose former employer's confidential information when required to do the same or a similar job for a new employer ${ }^{32,40}$.

Although the inevitable disclosure doctrine has been widely adopted or endorsed in many jurisdictions in the world $^{32,40}$, the doctrine is applied in very narrow circumstances and only when the court is satisfied with the situation that the former employer and current employer are competitors. In this case, the employee's position would be comparable to the former position and where the precautions taken by the current employer against the usage of trade secrets are inadequate, the doctrine would be applied ${ }^{41}$.

\subsubsection{Remedies for employment related trade secrets misappropriation}

The majority of jurisdictions rely primarily on civil remedies for the enforcement of trade secrets protection $^{42,}{ }^{43}$. The most common remedy for misappropriation of trade secrets is injunction that stops disclosure or misuse of information ${ }^{44}$. The court may award an interlocutory injunction (preliminary relief) or permanent injunction subject to the facts of the case ${ }^{1}$. 
A swift means to stop disclosure or dissemination of trade secrets is an interlocutory injunction ${ }^{45}$. Unlike the loss of other tangible property, the loss of trade secrets is irreparable, and to avoid or mitigate trade secrets loss, swift action is essential to prevent the imminent disclosure or an ongoing breach of confidence ${ }^{46}$. An interlocutory injunction may, depending on its terms, stop an employee working for the new employer, or eliminate the use of alleged trade secrets until a substantial trial. Interlocutory injunctions are upheld widely to eliminate any unfair head start a wrongdoer may attain through misappropriating another's trade secrets ${ }^{47}$.

The court may also decide that for a period of time the employee is prohibited from disclosing confidential information obtained during the course of employment. In the cases of breaching confidence, relief can be divided into two types: injunction against disclosure and injunction against continued use ${ }^{1}$. The main concern when issuing a permanent injunction is time and timing, the court needs to decide how long it should be in effect and when that period shall start. However, when the information is inseparable from an employee's general skill and knowledge, the court may issue an inevitable disclosure injunction. The court fashions the relief based on the particular circumstances in the case, and the injunction rarely last for one year or more ${ }^{48}$.

\subsubsection{Employee's confidentialities under Chinese law}

The current legal framework in China provides an array of mechanism for trade secrets protection ${ }^{49}$. They include: protection provided by Anti-Unfair Competition Law (ACL), contract law, tort law, criminal law, and additional trade secrets legislation. The ACL established the most comprehensive and effective statutory framework for trade secrets protection in China ${ }^{50}$. The ACL banned three categories of activities infringing upon trade-secret rights ${ }^{51}$ :

- To attain trade secrets through theft, enticement, coercion or other undue measures.

- To disclose, use or allow others to use trade secrets obtained by undue measures.

- To disclose, use or allow others to use trade secrets obtained by breaking an engagement or disregarding the requirement to maintain confidentiality.
Another source of employee's confidentiality comes from the contract law ${ }^{8}$. The Labor Law of China, which came into effect on 1 January 1995, provides that the parties of an employment contract may stipulate the terms addressing the employer's trade secrets protection (Article 22). However, some broadly adopted solutions such as non-competition restrictions are not included in this legislation and, therefore, still remain nebulous in terms of their legal effects ${ }^{52,53}$.

The Employment Contract Law which came into force on 1 January 2008 was the first law specifically governing employment relationship in China. The law explicitly endorses employers' attempts to protect their trade secrets by specifying non-disclosure or noncompeting clauses within the employment contract, or alternatively in the form of a separate confidentiality agreement (Employment Contract Law, Article 23-24). An agreement preventing employees from engaging in competition with their former employer is an essential supplement for the statutory protection of trade secrets. Without this, trade secrets owners can only seek remedies after their secret has leaked out, which is often criticized as being futile since the loss of trade secrets is not retrievable. A non-competition agreement takes certain precautionary measures by prohibiting former employees working for a competitor, and thus can avoid the 'unavoidable disclosure' which occurs in cases where the former employee converts to a rival competitor $^{54}$.

The available remedies under the Contract Law in the case of breach of confidential obligation include actual damages and liquidated damages. Article 112 of the Contract Law provides that where a party fails to perform its contractual obligations and the other party has sustained loss, the breaching party shall pay damages. Article 113 prescribes that the amount of damages payable shall be equivalent to the other party's loss resulting from the breach, including any benefit that may be accrued from performance of the contract, provided that the amount shall not exceed the likely loss resulting from the breach which was foreseen or should have been foreseen by the breaching party at the time of conclusion of the contract. Article 114 provides liquidated damages. The parties of a confidentiality agreement may prescribe that if one party breaches the contract, it will pay a certain sum of liquidated damages to the other party in light of the degree of breach, or 
prescribe a method for calculation of damages for the loss resulting from a party's breach.

The Employment Contract Law provides liquidated compensation for trade secrets loss. Article 23 of the Employment Contract Law provides that if the employee breaches the anti-competition restriction, he/she shall pay the employer liquidated compensation as agreed.

\subsection{Inter-organizational trade secrets program}

There are no easy solutions to the problems of trade secrets divulgence in the information $\operatorname{age}^{55}$. Trade secrets programs within organizations need to give full consideration to the legal framework and address common risk factors for trade secrets loss.

\subsubsection{Physical security}

Inter-organizational security procedures deal with information dissemination within the organization. By restraining employees' access to sensitive areas or facilitates in the work place, and only granting some key employees with access to the confidential information, an organization can control its trade secrets on a needto-know basis. Normally such key employees are bound by a written non-disclosure agreement or implied duties not to disclose the employer's trade secrets ${ }^{56}$.

Other than the restraints on access to confidential information, there is a growing trend of technically monitoring employee's on-the-job performance in the work $_{\text {place }}^{57}$. Employers often take a range of approaches to monitor the workplace and employee's performance to protect their trade secrets ${ }^{58}$, those include: monitoring internet connections, storage and review of e-mail messages, storage and review of computer files, recording and review of telephone conversations, storage and review of voice mail messages, and so forth.

\subsubsection{Written agreement and rules}

The employer's trade secrets protection program starts at recruitment of employees, one easy but useful step is to require the new hire to sign non-disclosure agreement ${ }^{59,60}$. Often as a condition of employment, employees are required to sign an agreement "acknowledging that the employment creates a relationship of confidence and trust with respect to confidential information"61.
Some key employees whose position involves the employer's critical trade secrets are generally required to sign a non-compete agreement that extends such contractual obligations to the post-employment phase, under such an agreement, the departing employee should not work for a competitor, or start up his or her own business competing with the former employer ${ }^{34}$. In addition, if a newly hired employee has ever worked for a competitor, the new employer may ask the employee to sign an agreement to assure the former employer's trade secrets are not disclosed or used during the new employment ${ }^{59}$.

Employees also have duty to abide by the organizational work procedures to secure trade secrets ${ }^{62}$. For example, to record daily activities, prepare progress reports and screen all information going outside of the organization. The policy should be in a written form lest it be enforced in a lax manner and eventually ignored ${ }^{63}$.

\subsubsection{Employee awareness procedure}

Given the fact that trade secrets owners can rely on absolute secrecy to maintain control on their valuable information without the need for protection granted by trade secrets law, such control is often challenged by the necessity of sharing information with personnel who need access to trade secrets ${ }^{38}$. Quite to the contrary, some companies are reluctant to establish certain safeguards based on the assumption that in doing so would remind employees of the existence of secret information and draw undue attention on it. However, it has been frequently held by the court that the law cannot enforce trade secrets if the owner does not take reasonable security measures ${ }^{64}$.

Employee awareness procedures convey what trade secrets are in an organization and what employee's obligations are in terms of trade secrets protection ${ }^{65}$. Employee awareness procedure normally contains three steps $^{63}$ :

The first step is to ensure an employee's familiarity with the company's security procedures when employment commences. At this stage, the easiest and most useful way is to require employees to sign a nondisclosure agreement ${ }^{66}$. The second step is to periodically remind employees of duties of confidentiality during the course of employment. Employees who are involved in dealing with a company's trade secrets should sign a minute acknowledging they have accessed to company's trade 
secrets $^{63}$. The third step is to conduct exit interview to ensure the employee's awareness of their postemployment obligations of non-disclosure or noncompetition $^{18,67}$. If possible, the employer should advise the new employer regarding the employee's nondisclosure obligations ${ }^{66}$.

In summary, most trade secrets divulgence is via employees' activities; therefore employees are the significant contributors to the loss of intellectual assets. Businesses simply cannot rely on secrecy to protect valuable information, because sharing information is the basic requirement to run a business in the context of globalization. Trade secrets law commonly addresses employee's confidential liability to facilitate information sharing within organization. Corresponding remedies will be enforced by the law when breaching such liability, thus an alternative way is provided to compensate for trade secrets loss.

\section{Research Methods}

With the aim of exploring trade secrets protection in the context of employment in China, a case study strategy is adopted in this study as it is suitable for explorative inquiry and gaining knowledge in context rather than formal generalization $^{68}$.

\subsection{Case selection}

A two-case design was adopted in this study to derive direct replication ${ }^{69}$ since conclusions drawn from more than one case is more powerful that those coming from a single case. The Anti-unfair Competition Law of China (ACL, 1993) classifies business secrets into technical information and operational information that is not known to the public. The trade secrets programs in the selected organizations under study should be of recognized prominence, and represent either end of the continuum from technical to operational information. At the same time, one large and one small organization have been deliberately included to further address the contrasting situations ${ }^{70}$.

Virtually all businesses have trade secrets in today's knowledge-based economy ${ }^{15}$, but not all businesses have robust perceptions of trade secrets ${ }^{71}$. Another important consideration in case selection is to choose exemplary cases $^{72}$ that have robust trade secrets operations in place. Other than that, pragmatic considerations are unavoidable in this study as in reallife research convenience and cost tend to be considered as well ${ }^{73}$. The case selection in this study was thus guided by the considerations as below:

- Trade secrets must be a significant form of intellectual property in the selected organizations; the organization had reported trade secrets loss within the past five years.

- Trade secrets in both forms, technical and operational, should be reflected in the selected organizations.

- The selected organizations differ in their business scales. For example, large nation-owned enterprise, or family-operated small business.

- The selected organizations need to be accessible. Initially, a list of five enterprises was provided. Those enterprises were then contacted by a telephone call informing the purpose of this investigation and the confidentiality of the information gathered. They were given an assurance that no identifying information would be disclosed, and the researcher promised to destroy any written or audio recorded information if requested to do so. The phone call was followed by an email conveying a formal invitation to participate in this study. Eventually, two enterprises with different industrial backgrounds and different types of trade secrets protocols were selected as the cases for the field investigations.

Enterprise $\mathrm{A}$ is a high-tech enterprise in the biochemical industry. As a publicly listed company, it engages in a range of businesses covering research, manufacture and sales of bio-pesticides, bio-veterinary drugs and their intermediates. More than 300 employees (out of 1,500 in the whole enterprise) work in the Research \& Development department. Accordingly, technological information plays a significant role in terms of the sources of trade secrets in this enterprise. The legal division of the administrative department oversees the trade secrets-related affairs.

Enterprise $\mathrm{B}$ is a middle-sized trading company specializing in importing and exporting. As a nationally owned enterprise, this company enjoyed a monopoly status for decades in the planned economy. It lost monopoly once the market-economy policy prevailed in China and, in return, it was released from the government-imposed duties. There are over 200 employees in this company, of which most mid-to-top management have global horizons, and its largest client group is from North America. The competitive advantage of this company lies in its network of market information and its ability to exploit niche markets. 
Thus, business information, such as client's lists, forms the overriding source of trade secrets in this company.

As a state owned company, the general manger, normally appointed by the government, is the ultimate decision-maker in the company. During the last five years, the company was restructured twice with to the aim of enabling it to fit in with the ever-changing situation of the market. The present organizational structure is product-oriented rather than client-oriented. A deputy general manager was assigned the responsibility of managing intellectual property in which trade secrets were included.

\subsection{Data collection}

The research questions in this study are mainly 'how' and 'why' questions. Given the type of information needed in this research, the following techniques were employed in primary data collection: observations, document analysis and focus group interviews. In this research, direct observation ${ }^{69}$ was used to gain an intuitionistic impression of how the trade secrets program runs on an everyday basis so that, as an alternative source of data, the information collected through observation can facilitate a full understanding of relevant information arising from subsequent interviews $^{69}$.

The observations lasted for one week in Enterprise $\mathrm{A}$ and covered the full range of the security operations of the enterprise under study, while in Enterprise B, the enterprise could not facilitate longitudinal observations, and therefore, a one-shot observation was undertaken instead. The observation protocol which covers the field settings, events, the governing policy within the organization, and the interpretations of the events and the policy, was formed to guide the observation ${ }^{74}$. Thus the written strategies, policies, and miscellaneous documents associated with trade secrets protection in this organization were collected as a benchmark against which the actual implementing activity could be evaluated. An observation diary was made and an onsite interview was conducted with employees whose duty or position was involved with the phenomenon under observation. What they did and the meaning they gave to their behavior were recorded during the observation.

Focus group interviews in this study were based on three considerations: First, to fully understand the meaning of the phenomenon under study by allowing interviewees to freely give their description and explanation in their own words ${ }^{75}$; Second, to avoid a failure to inquire into meaningful phenomena that might occur in a structured interview; Third, to encourage spontaneity in respondents' answers ${ }^{76}$. Group interactions can encourage the participants to voice their opinions and respond to the others, thus focus group discussion can provide information inaccessible without group interactions ${ }^{77}$.

In Enterprise A, the researcher was allowed to select any employees to take part in the group discussion. Eventually six people were included in the interview: the manager of the legal department, the manager of the human resource department, the head of security, and three engineers who bore the obligation of confidentiality (hereinafter focus group A). In Enterprise B, after discussing with the general manager, seven respondents were selected to take part in the interview, including the general manager and six department managers who have close access to the trade secrets of this company (hereinafter focus group B).

The participants of the third focus group included trade secrets professionals: one lawyer whose legal practice focuses on trade secrets litigation, one university professor who majored in intellectual property management, one justice from the intellectual property division of the High Court of Hebei Province, one government official from the fair-competition office of a provincial administration of industry and commerce, one senior staff member from the Commission of Legislative Affairs of provincial parliament, and one government official from a State-owned Assets Supervision and Administration Commission (hereinafter focus group C).

\section{Analysis and findings}

\subsection{Overriding motivations for trade secrets divulgence identified in the case studies}

During the one-week onsite observations in Enterprise A, altogether 38 employees who have an obligation of confidentiality were interviewed, and comments were solicited on the phenomenon of employees divulging their employer's trade secrets for private gain. Over 58 percent of interviewees regarded the phenomenon as 'unethical' in general, but nearly half of them agreed that such actions would be less likely to occur if employees were fairly treated during their employment. 
In the focus group discussions, participants were asked for comments on the same issue. It was believed that the traditional attitudes towards stealing others' proprietary technology and commercial information no longer prevailed in the current business environment. Trade secrets misappropriation was purely triggered by self-interests. In most occasions other's trade secrets were misused under clear consciousness of wrongdoing, but the material benefits were more persuasive than the workplace ethics. In the words of one participant of this focus group: "it was just a matter of weighing and choosing between possible benefits and potential risks. When benefits override risks, they (the employee) would betray their employer and disclose their business secrets".

The discussion in focus group B revealed that a tremendous amount of small and medium-sized enterprises, largely from the private sector, entered into export trade business as a result of the foreign trade reform which started in 1994. To survive the fierce competition, these small firms desperately sought business opportunities by rewarding the provider with remuneration commensurate to the market value of the opportunity. One participant in this group described this foreign trade reform as a 'frustration' to large stateowned foreign trade enterprises, because it promoted 'unethical competition' which encouraged trade secrets misappropriation. However, most participants in the focus group meetings ranked self-interest, not something else, as the overriding trigger for trade secrets divulgence. The discussion also revealed that a large proportion of trade secrets divulgence was conducted by employees who had ever contributed to creating the secrets with an expectation for rewards. Once they were not satisfactorily remunerated, they would take it as a pretext for 'self-remuneration' by unduly exploiting those secrets.

The discussion in focus group $\mathrm{C}$ demonstrated that the influence of the traditional view on intellectual property rights has waned dramatically as the economy and society develops. For many employees, trade secrets misappropriation is no longer a judgment of right or wrong, it is weighing of costs and profits. Without sufficient deterrence, the rampant misappropriation will be an ongoing process.

\subsection{Workforce fluidity as an influential factor}

It was confirmed that in enterprise A, all trade secrets misappropriation were employee related. In other words, all divulgences ever happened in this company were committed by departing employees. In enterprise B, more than half of trade secret thefts occurred when the employee left the enterprise.

The focus group interview in enterprise A revealed that it was technically untenable for an employee to disclose sophisticated technical information to a competitor while maintaining a normal attendance rate to the current job, as such a transaction normally require intensive training to the receiving party. Most treacherous employees selected to leave the current job because it otherwise would be apparent that they were the ones who had divulged the trade secrets. Therefore, to some extent the mobility of employee engenders trade secrets divulgence, while sometimes the divulgence necessitates employee mobility.

In contrast with enterprise $A$, the main form of trade secrets in enterprise B was marketing information which is less technically sophisticated and could be more conveniently replicated, and possibly be retained in the memory of those who have access to it. The former employees can only be competent for what they used to be specialized in, and they will do the same thing after they left the company. The knowledge acquired during the previous employment will inevitably be applied to their new job. Therefore, this company has experienced fierce competition as a result of divulgence of client's information. Once the competitors acquired the client's information, they simply beat this company by offering a lower price to the clients, and triggered a price war.

The discussions in focus group $\mathrm{C}$ also shed light on the relationship between employee fluidity and trade secrets divulgence. Trade secret leakage was predicted to be a 'lifelong companion' of Chinese enterprises in the market economy.

\subsection{Employee's confidentiality under the law}

Both case enterprises hailed the ECL as legal endorsement for their controversial anti-competition policies prior to the promulgation of the law. More than half the participants in focus group A agreed that the anti-competition agreement was essential to protect trade secrets. Some secrets may have embedded in the employee's memory and integrated into his general skills, and if he/she were allowed to work in a similar 
position for a competitor, he/she could by no means be prevented from using what he/she had learned during the former employment.

All participants in focus group B concurred that a non-competition relationship existed between the employer and the employee, and the ECL erased the nebulous situation regarding the legality of including anti-competition provisions in the employment contract. Focus group $\mathrm{C}$ welcomed the enactment of the ECL in general. The discussions highlighted that the anticompetition mechanism requires commitment from both sides to the contract. That is, the employee's noncompetition obligations should be rewarded with a sound remuneration for a reasonable period of time. Insufficient remuneration has been a common concern in the implementation of such anti-competition agreements.

\subsection{Employee awareness procedures}

\subsubsection{Pre-employment awareness}

In enterprise A, standard clauses prohibiting employees from disclosing trade secrets were included in the employment contract. All newly recruited employees were required to sign such a contract prior to the commencement of their employment, and additional non-compete clauses were included for those who applied for critical positions. A non-compete agreement prohibits employees from taking similar positions in a rival company, or embarking on a competing business for certain period of time after terminating their employment.

Enterprise B was one of the first few import \& export companies to include non-compete agreements in their employment contracts. In this company every employee was required to sign a contract incorporating non-compete clauses before commencing their employment. The non-compete clauses prohibit the employee from misusing the company's trade secrets, working for a rival company, or engaging in a competing business during their employment and for two years after the employment with the firm ceases. The focus group meeting held in this enterprise revealed that the performance of the non-compete contract remained problematic, since most employees were under paid for the non-competing period of time, which would obviously breach the ECL.
To address this concern, this company launched a restructuring program to introduce after-employment remuneration into the employment contract, which would provide those employees with $80 \%$ of their monthly earnings for the non-competing duration. It is worth mentioning that the personnel who were bound by non-competing obligations shrank to skeleton size after the restructure.

\subsubsection{Amid-employment reminding program}

In Enterprise A, the on-site observation found that a trade secret education program was in progress, in which the employees were informed of obligations of confidentiality by a range of devices, such as periodically issued newsletters, slogans attached on the walls of the staff canteen, the pop-up warning flash on the company's website, series of seminars and knowledge contests. The program aimed to construct an environment that regards trade secrets as priceless assets of the company.

One seminar was observed in which an arbitrator from the Employment Dispute Arbitration Committee of local government was invited to give a lecture about employees' obligations of confidentiality. After the seminar, twelve members of the audience were interviewed for comments on the lecture. Five of them explicitly dubbed it as a "tedious platitude", and asserted that "people will do whatever they think expedient"; four of them diplomatically labeled it as an "understandable" step for managing a business; and three of them declined to comment.

The newsletters were displayed in the staff reading rooms, conference rooms and all department offices of this enterprise. The content of the newsletter mainly focused on discussion of the Employment Contract Law, interspersed with the accounts of several trade-secret law cases. It was noticed that quite a few paragraphs in the newsletters addressing employee's confidential obligations were highlighted or underlined, which implied that particular attention were paid on such points. Nine readers were invited to give reasons why those sections attracted particular attention. The explanations generally fell into three categories:

- acquiring knowledge to avoid trouble if changing jobs in the future,

- assessing personal loads of obligations against legitimate standards,

- formulating personal career plans. 
In Enterprise B, the plenary meeting of staff members was chosen as an ordinary channel for conveying trade secret education. The company's trade secrets policies and related legal regulations were reiterated at those meetings in the belief that the regularly sounded tocsin serves as the best instrument to remind the employee of their confidential obligations.

This enterprise also put great efforts into cultivating an organizational culture in favor of intellectual property rights. A "non-pirate-product" policy was strictly carried on in this company. "This policy is quite helpful to foster an atmosphere of respecting intellectual property rights within the company, notwithstanding we have to pay a heftier costs for lawful products. The inter-organizational atmosphere facilitates diminishing reckless divulgence of trade secrets", one participant said at the group interview. It was also suggested that a good faith and honesty record system should be established in the whole society, so that unfaithful employees might be placed on a "black list", which would impact negatively on his future career. Such a "black list" was believed to be able to curb the misappropriation effectively.

\subsubsection{Pre-departing interview}

In Enterprise A, a departing employee would be reminded about confidential obligations in the farewell interview. In Enterprise B, a pre-departing interview was common to reiterate the non-competing obligations of the departing employees. However it was revealed in the focus group meeting that the interview was conducted only when necessary.

Trade secrets awareness programs were also discussed at length in focus group C. It was highlighted that the awareness level of the management significantly influenced the implementation of the organizational trade secrets policy, and that the employees' awareness could diminish trade secrets divulgence. A non-competing clause included in the employment contract was seen as the most effective precaution; however a unilateral non-competing contract without considerable remuneration was likely to be rejected by the court, for it would breach the ECL.

\section{Conclusion}

The results of this study indicate that trade secrets program facilitates organizational competitive advantage by keeping valuable information out of the hands of competitors. To achieve this goal, such program should integrate legal protect mechanisms and non-legal measures to maintain secrecy. At the same time, protective steps taken within an organization should be in compliance with the requirement set forth by the law, otherwise the court may not grant any remedies for the loss of confidential information. The awareness program was recommended to cover the entire employment process from recruitment stage to the pre-departure phase.

Notwithstanding that the Civil Procedure Law of China provides property preservative measures (Article 92) in litigation, which was deemed as functionally similar with the injunction in Anglo-American law ${ }^{78}$, the preservative measures are to a large extent a vehicle to guarantee the execution of the judgment (Article 92 of Civil Procedure Law), and the preservative measures should be released upon satisfactory guarantee by the responding party, in this case, the preservative measures cannot prevent the infringement of trade secrets, therefore judicial injunctions should be introduced into China's trade secrets law ${ }^{79}$.

\section{References}

1. A.K. Rawlings, Trade secrets in a knowledge-based economy (2001), Dissertation for the degree of Master of Law, University of Toronto.

2. K. E. Maskus, Intellectual property rights and economic development, Case Western Reserve Journal of International Law, 32 (2000) 471-506.

3. K.A. Magri, International aspects of trade secrets law (1997), Online available at http://www.myersbigel.com/library-articles/internationalaspects-of-trade-secrets-law-by-karen-a-magri (accessed July 2, 2013).

4. M. Deutch, The property concept of trade secrets in Anglo-American law: an ongoing debate, University of Richmond Law Review, 31 (1997) 313-369.

5. K. Li, How to protect trade secrets, The China Business Review, 32(3) (2005) 36-40.

6. Y. Dai, Farewelling the old time and greeting new economy', Digest of Management Science, 6 (2000) (in Chinese)

7. W. Hennessey, Deconstructing Shanzhai - China's Copycat Counterculture: Catch Me If You Can. Campbell Law Review, 34 (2012) 609-660.

8. M.A. Pagnattaro, "The Google Challenge": Enforcement of Noncompete and Trade Secret Agreements for Employees Working in China, American Business Law Journal, 44 (2007) 603-637. 
9. Y. Cheng, Legal protection of trade secrets in the People's Republic of China, Pacific Rim Law \& Policy Journal, 5 (2) (1996) 261-296.

10. C.L. Zhang, On legal protection of Trade secrets, Commercial Research, 1 (1) (2002) 23-25 (in Chinese).

11. A. Coleman, The legal protection of trade secrets, (Sweet \& Maxwell, London, 1992).

12. K.I. Phair, Enabling American high-tech companies to protect their secrets abroad: A comparative analysis of Irish and American trade secrets regulation, Hastings International and Comparative Law Review, 24 (2001) 507-538.

13. M.P. Simpson, The future of innovation: trade secrets, property rights and protectionism-and age-old tale, Brooklyn Law Review, 90(3) (2005) 1121-1164.

14. B.J. Love, and C.B. Seaman, Best Mode Trade Secrets. Yale Journal of Law and Technology, 15 (2013) 1-23.

15. S.D. Marrs, Inside story on trade secrets: protective measures are necessary to preserve a company's vital information, American Bar Association Journal. 10 (2000) 77.

16. Fenwick \& West LLP, Trade secrts protection: a primer and desk reference for managers and in house counsel (2003), Online available at

www.fenwick.com/intellectual_property/trade_secrets/tra de_secret_protection.pdf (accessed Aug. 12, 2013).

17. W. M. Fitzpatrick, Uncovering trade secrets: the legal and ethical conundrum of creative competitive intelligence, S.A.M. Advanced Management Journal, 68 (3) (2003) 4-13.

18. M.A. Pagnattaro, Preventing know-how from walking out the door in China: Protection of trade secrets. Business Horizons, 55 (2012) 329-337.

19. W.M. Fitzpatrick, S.A. DiLullo and D. R. Burke, Trade secret piracy and protection: corporate espionage, corporate security and the law, Advances in Competitiveness Research, 2 (1) (2004) 57-72.

20. N. Swartz, Safeguarding corporate secrets, Information Management Journal, 40 (1) (2006) 24-30.

21. D. Drab, Economic Espionage and Trade Secret Theft: Defending against the pickpockets of the new millennium: U.S. Attorney General's Office (2003). Online available at

http://a1851.g.akamaitech.net/f/1851/2996/24h/cache.xer ox.com/downloads/usa/en/c/cert_WP1_EETS_red.pdf (accessed Jan. 22, 2013).

22. J. Xu, G. S. Shankar Sankaran, and D. Clarke, Knowledge management in twenty-first century: literature review and future research directions, The International Technology Management Review, 1(2) (2008) 16-24.

23. X. J. Shi, On the conflict and harmonization between trade secrets protection and talent migration, Market Modernization, 481 (2006) 292-294 (in Chinese).

24. D.J. Teece, Capturing Value from Knowledge Assets. California Management Review, 40 (1998) 55-79.
25. A.A. Schiller, Trade Secrets and the Roman Law, The Actio Servi Corrupti, Columbia Law Review, 30(6) (1930) 837-845.

26. C. Heer, Employees and trade secrets: How the concept of inevitable disclosure may fit into Canadian law, Intellectual Property Journal, 19(2) (2006) 323-349.

27. J.H Reichman, Trade secrets and confidential information, in Intellectual property and international trade: the TRIPS Agreement, 2nd edn, eds, C.M. Correa and A.A. Yusuf (Kluwer Law International, 2008), pp. 58-60.

28. C. Anita, Trade secrets and covenants not to compete: beware of winning the battle but losing the war, Journal of Small Business Management, 28(4) (1990) 99-103.

29. A.M. Franco and M.F. Mitchell, Covenant not to compete, labor mobility, and industry dynamics (2005)', Online available at: www.lse.ac.uk/collections/accountingAndFinance/news/ RICAFE2\%204_5\%20Oct.pdf (accessed Aug. 03, 2013).

30. J.D. Hertog, Non-competition clauses: Unreasonable or efficient? European Journal of Law and Economics, 15(2) (2003)111-127.

31. S.M. Gutierrez, J.D. Neguse, and S. Collis, 2010. The Human Limits of Human Capital: An Overview of Noncompete Agreements and Best Practices for Protecting Trade Secrets from Unlawful Misappropriation, Employee Relations Law Journal 36 (2010) 60-76.

32. M.J. Garrison, and J.T. Wendt, The evolving law of employee noncompete agreements: Recent trends and an alternative policy approach. American Business Law Journal, 45 (2008)107-186.

33. R.M. Milgrim and E.E. Bensen, Use of agreements to protect trade secrets in the employment relationship. Milgrim on Trade Secrets 2 (2013).

34. J.D. Ingram, Covenants not to compete, Akron Law Review, 36 (2003) 49-79.

35. N.D. Bishara and M. Westermann-Behaylo, The Law and Ethics of Restrictions on an Employee's PostEmployment Mobility. American Business Law Journal, 49 (2012) 1-61.

36. D.R. Hannah, An examination of the factors that influence whether newcomers protect or share secrets of their former employers. Journal of Management Studies, 44 (2007) 465-487.

37. E.S. Tautfest, Temptations to take: misappropriation of trade secrets, damages and remedies, Computer Law Review and Technology Journal, 7 (2003) 17-148.

38. B. A. Rodau, Trade secrets-the new risks to trade secrets posed by computerization, Rutgers Computer \& Technology Law Journal, 28 (2002) 227-274.

39. W.G. Porter and M.C. Griffaton, Using non-compete agreements to protect legitimate business interests, Defence Council Journal, 69 (2) (2002) 194-202.

40. E.M. Kaplan and M.M. Hanlon, The doctrine of inevitable disclosure, FDCC Quarterly, 54 (3) (2004) 259-264.

Published by Atlantis Press

Copyright: the authors 
41. M.D. Carlson, Trade secrets: Is the inevitable doctrine inevitable?, Intellectual Property Law Bulletin, 1 (1996) 11-18.

42. D. Newman, M. Cai and R. Heugstenberg, 2007 Intellectual property crimes, The American Criminal Law Review, 44 (2) (2007) 693-744.

43. I.N. Chatterjee, Should trade secret appropriation be criminalized?' Hastings Communications and Entertainment Law Journal, 19 (1997) 853-898.

44. S. M. Kline and M. C. Floyd, Managing confidential relationships in intellectual property transactions: use restrictions, residual knowledge clauses and trade secrets The Review of Litigations, 25 (2) (2006) 311-347.

45. R. Dean, The law of trade secrets (The Law Book Company Limited, Sydney, 1990).

46. A. Beckerman-Rodau, The choice between patent protection and trade secret protection: A legal and business decision. Journal of the Patent \& Trademark Office Society, 84 (2002) 371-409.

47. R.C. Dorr and H.H. Munch, Protecting trade secrets, patents, copyrights, and trademarks (John Wiley \& Sons, INC. 1995).

48. W.L. Schaller, Trade secrets inevitable disclosure: substantive, procedural \& practical implications of an involving doctrine, Journal of the Patent and Trademark Office Society, 86 (2004) 336-358.

49. J.B. Bai and G. Da, Strategies for Trade Secrets Protection in China. Northwestern Journal of Technology and Intellectual Property, 9 (2011) 351-375.

50. Y. Li, Confidential Archives of Chinese Civilization (Baihua Literature \& Arts Press, Tianjin, 2005) (in Chinese).

51. X. Yang, On trade secrets protection under competition law (2007), Online available at www.fatianxi.com/paper_list.asp?id=13981 (accessed Jul. 26, 2013) (in Chinese).

52. X. S. Huang and Y. C. Lin, Perfecting the system of Noncompetition in China, Journal of Chongqing University (Social Science Edition), 12(1) (2006) 76-80 (in Chinese).

53. V. Weinstein and D. Fernandez, Recent develops in China's intellectual property law, Chinese Journal of International Law, 3 (2004) 227-240.

54. J.P. Gui, On some issues of non-competition restriction, Law \& Trade Research, 1 (2001) 11-20 (in Chinese).

55. S. J. Willert, Safeguarding trade secrets in the information age, Practical Lawyer, 49 (1) (2003) 11-26.

56. T. A. Hemphill, The strategic management of trade secrets in technology-based firms, Technology Analysis \& Strategic Management. 16 (4) (2004) 479-494.

57. S. Sarpong and D. Rees, Assessing the effects of 'big brother' in a workplace: The case of WAST. European Management Journal (in Press).

58. K. Ball, Workplace surveillance: an overview. Labor History, 51 (2010) 87-106.

59. R.C. McCrea, Protecting trade secrets and confidential business information, Practical Lawyer, 44 (5) (1998) 71-90.
60. M. A. Hood, Protecting your company's confidential information and trade secrets from misappropriation by departing employees, Orange County Business Journal, 30 (25) (2007) 36.

61. E. A. Rowe, When trade secrets become shackles: fairness and inevitable disclosure doctrine, Tulane Journal of Technology and Intellectual Property, 7 (2005) 167-330.

62. K. Medd and A. Konski, Workplace programs to protect trade secrets, Nature Biotechnology, 23 (2003) 201-203.

63. M. A. Epstein and S. D. Leui, Protecting trade secret information: a plan for proactive strategy, The Business Lawyer, 43 (1988) 887-914.

64. M.C. Budden, R. C. Lake, and S. L. Lett, Protecting trade secrets, Management Accounting, 72 (6) (1990) 45-47.

65. D.R. Hannah, An investigation of the effects of trade secrets protection procedures and psychological contract violations on employees' tendencies to divulge trade secrets', Ph.D dissertation. University of Texas at Austin (2000).

66. M. A. Hood, Protecting your company's confidential information and trade secrets from misappropriation by departing employees, Orange County Business Journal, 30 (25) (2007) 36.

67. D.W. Quinto, and S.H. Singer, Trade secrets: law and practice (Oxford University Press, 2009).

68. R.K. Yin, Case study research: design and methods, 4th edn. (Sage Publications, Thousand Oaks, CA., 2009).

69. R.K. Yin, Case study research: design and methods, 3rd edn. (Sage Publications, 2003).

70. A.J. Veal, Business Research Methods: A Managerial Approach, 2nd edn. (Pearson Education Australia, 2005).

71. Y. X. Wang and W.Q Wu, Survey and analysis on trade secrets protection, People's Judicature, 4 (2004) 14-17 (in Chinese).

72. B. Flyvbjerg, Five Misunderstandings about Case-Study Research. Qualitative Inquiry, 12(2006) 219-245.

73. M.Q. Patton, Qualitative research and evaluation methods, $3^{\text {rd }}$ edn. (Sage Publications.,2002).

74. J. W. Creswell, Qualitative Inquiry Research Design: Choosing Among Five Approaches, $3^{\text {rd }}$ edn.(Sage Publications, 2013).

75. D. Carson, A. Gilmore, C. Perry, and K. Gronhaug, Qualitative Marketing Research (Sage Publications, 2001).

76. A. Bryman, and E. Bell Business Research Methods, $2^{\text {nd }}$ edn. (Oxford University Press, New York, 2007).

77. D.L. Morgan, Focus groups as qualitative research (Sage, Newbury Park, 1988).

78. Y.S. Yang, Set up injunctive remedy for trade secrets in China, Electronics Intellectual Property, 9 (2002) 53-56 (in Chinese).

79. J.J. Zhu, Several issues on trade secrets infringement cases, Qiu So, 12 (2005) 108-109 (in Chinese).

Published by Atlantis Press

Copyright: the authors 